\title{
Assessing Land Cover/ Land Use Change and its Impacts on Surface Water Quality in the Ziarat Catchment, Golestan Province-Iran
}

\author{
Mojtaba Zamani ${ }^{*}$, Amir Sadoddin² and Arash Zare Garizi ${ }^{2}$
}

${ }^{1}$ Gorgan University of Agricultural Sciences and Natural Resources, Department of Environment, Gorgan, Iran

${ }^{2}$ Gorgan University of Agricultural Sciences and Natural Resources, Department of Watershed Management, Gorgan, Iran

\begin{abstract}
This paper outlines a study aimed to assess the long-term association between land cover/land use change and water quality changes occurred in the Ziarat Catchment, upstream of the Gharasoo River basin, Golestan Province northeast, of Iran. To assess the significance of trends in the time series of water quality variables, non-parametric trend tests (the Mann-Kendall and the seasonal Kendall) or parametric trend tests (linear regression and ANCOVA) were performed after removing variance due to discharge. The water quality and quantity data available for the analysis in this study belong to the observed period from 1974 to 2012 in a river gauge station located at the outlet of the catchment. The analysis revealed that with the exception of $\mathrm{pH}$ (no trend) and sulfate (negative trend), all other water quality variables including electrical conductivity, total dissolved solids, hardness, sodium, potassium, calcium, magnesium, chloride, sodium adsorption ratio and bicarbonate demonstrate statistically significant positive trends $(P$-value $<0.05)$. Using the seasonal Kendall test, the negative trends have been detected for rainfall and mean discharge time series. To determine the likely responsible factor(s) for water quality changes, an investigation has been conducted on land cover/land use changes. A series of significant land cover/land use change were identified from 1967 to 2012, within five time intervals, referring to satellite images and also aerial photographic interpretation and based on RS and GIS standard techniques. The spatial analysis shows that within four decades about 980 ha of forests in the catchment have been converted to other classes of land cover/land use (about $67 \%$ to croplands and/ or rangelands, $8.5 \%$ to residential 38 areas, $13 \%$ to bare lands, and $11.5 \%$ to roads). The results of this research suggest that land cover/land use change is one of the key factors causing water quality changes in the study area. The findings of this research assists policy makers and catchment managers in developing catchment management plans to protect and restore water quality conditions more effectively.
\end{abstract}

Keywords: Water quality; Land use change; Trend analysis; The Ziarat catchment

\section{Introduction}

Freshwater is a valuable natural resource whose quantity and quality is essential for sustainable development [1]. The quality of water has recently become as important as its quantity because water quality directly affects human and ecological health and the use of water resources. Also, water quality is important to assess the health of a watershed and to make necessary management decisions to control current and future pollution of receiving water bodies [2,3]. The information on water quality and pollution sources is important for implementation of sustainable water-use management strategies [4-7]. Surface water bodies are the potential recipients of the contaminations contained in surface runoff from their catchments [8]. Therefore, surface water quality management is extremely important. The chemical composition of surface water and its properties in a particular region is basically governed by natural processes such as precipitation rate, weathering processes, soil erosion and anthropogenic effects which is point or non-point sources of pollution such as urban, industrial and agricultural activities [9-11]. Surface water quality monitoring and the analyses of its temporal variations allow the detection and understanding of the effects of natural influences and anthropogenic disturbances on surface water quality [12]. It can also be helpful for better management of water resources and controlling current and future pollution of receiving water bodies [13]. Trend analysis of water quality data is an important environmental diagnosis of a catchment, allowing evaluations of how the water body responds during a period of several years, in qualitative terms, to the increase of anthropogenic interventions [13-16]. The purpose of trend testing is to determine if the values of a random variable generally increases (or decreases) during an intended time period in statistical terms $[17,18]$. The presence of trends in water chemistry provides an indication of environmental changes and gives insight into contributing factors such as changes in land use and management $[19,20]$. This study investigates the relationship between changes in land use/land cover and surface water quality in the Ziarat catchment (Golestan province, Iran). The Ziarat River is one of the tributaries of the Ghara-soo River. Currently, the Catchment of the Ziarat River is the water source for about 4000 inhabitants in rural area within the catchment as well as urban areas and agricultural fields in the downstream of the catchment. The river also provides 25 to 30 percent of drinking water of Gorgan (the largest city of Golestan province with about 500000 people). This is while the Ziarat catchment has long been subjected to land use change from forest to croplands and residential areas (Villas). So, there is growing concern about the potential effects of extensive land use change and resultant changes in hydrological conditions on the availability and quality of the water from this catchment. Despite its significance, there

*Corresponding author: Mojtaba Zamani, Gorgan University of Agricultural Sciences and Natural Resources, Department of Environment, Gorgan, Iran, Tel: +981714427040; Fax: +981714424155; E-mail: M_zamani2009@yahoo.com

Received May 15, 2013; Accepted June 11, 2013; Published November 21, 2013

Citation: Zamani M, Sadoddin A, Garizi AZ (2013) Assessing Land Cover/ Land Use Change and its Impacts on Surface Water Quality in the Ziarat Catchment, Golestan Province-Iran. Hydrol Current Res 4: 159. doi:10.4172/21577587.1000159

Copyright: ( 2013 Zamani M, et al. This is an open-access article distributed under the terms of the Creative Commons Attribution License, which permits unrestricted use, distribution, and reproduction in any medium, provided the original author and source are credited. 
is a lack of knowledge and understanding regarding the water quality of the Ziarat River and its spatiotemporal variations.

\section{Materials and Methods}

\section{Study area}

The Ziarat River is one of the tributaries of the Ghara-soo River in the Golestan province, Iran. The catchment has an area of about 9700 hectares which lies between latitude of $36^{\circ} 46^{\prime} 56^{\prime \prime}$ and $37^{\circ} 37^{\prime} 01^{\prime \prime} \mathrm{N}$ and longitude of $54^{\circ} 31^{\prime} 12^{\prime \prime}$ and $54^{\circ} 24^{\prime} 48^{\prime \prime}$ E northeast of Iran (Figure 1). The catchment has an altitude ranging from 670 to $3086 \mathrm{~m}$, a mean slope of $41.5 \%$. The mean annual precipitation is about $750 \mathrm{~mm}$. The underlying geology is mainly limestone formations, alluvial deposits near the streams and quaternary sedimentary formations and Schist, in the lowlands of the study area. Occurrence of debris flow is one of the main attributes of the river system in this catchment. The Ziarat catchment, mainly the lower part, has experienced unprecedented urban growth over the past three decades. This is in particular the case for the village of Ziarat as an important tourist destination in Golestan Province.

\section{Data}

Two types of data were used in this study: water quality data and land use data. The water quality data set of the Ziarat monitoring station (located at the outlet of the catchment) was obtained from the Golestan Province Regional Water Agency that takes samples of surface water every month and analyzes the samples using standard methods. The selected parameters for the assessment of surface water quality characteristics were river discharge (Q), Electrical Conductivity (EC), Total Dissolved Solids (TDS), pH, Total Hardness (TH), sodium $\left(\mathrm{Na}^{+}\right)$, potassium $\left(\mathrm{K}^{+}\right)$, calcium $\left(\mathrm{Ca}^{2+}\right)$, magnesium $\left(\mathrm{Mg}^{2+}\right)$, chlorides $\left(\mathrm{Cl}^{-}\right)$, sulfate $\left(\mathrm{SO}_{4}{ }^{2-}\right)$, and bicarbonates $\left(\mathrm{HCO}^{3-}\right)$. The water quality data available for the analysis in this study belongs to the observation period of $1974-2012$. The land use data were generated from aerial photographs (1967) and four Landsat multi-spectral images taken over a span of 24 years (Table 1 ).

\section{Long-term trend analysis of surface water quality}

Trend analysis determines whether the measured values of a variable increase or decrease during a time period. Several methods are available for the detection and/or quantification of trends: Graphical methods, regression analysis, Spearman's rho, Kendall's tau, and Sen's T tests. A comprehensive review of statistical approaches used for trend analysis of water quality time series is provided by Esterby [21]. Methods for trend analysis of water quality data should consider some of the characteristics commonly found in the water quality data. Some of these common characteristics are: non normality, missing values, outliers, seasonality, autocorrelation, and dependence on other variables such as rainfall or stream flow [22]. To this end, the underlying conceptual model used in trend analysis of water quality variable $\mathrm{Y}$ can be written as $\mathrm{Y}_{t}=X_{t}+S_{t}+T_{t}+\alpha_{t}(1)$. Where $\mathrm{Y}_{t}$ is the water quality observation at time $t, X_{t}$ is the exogenous variable

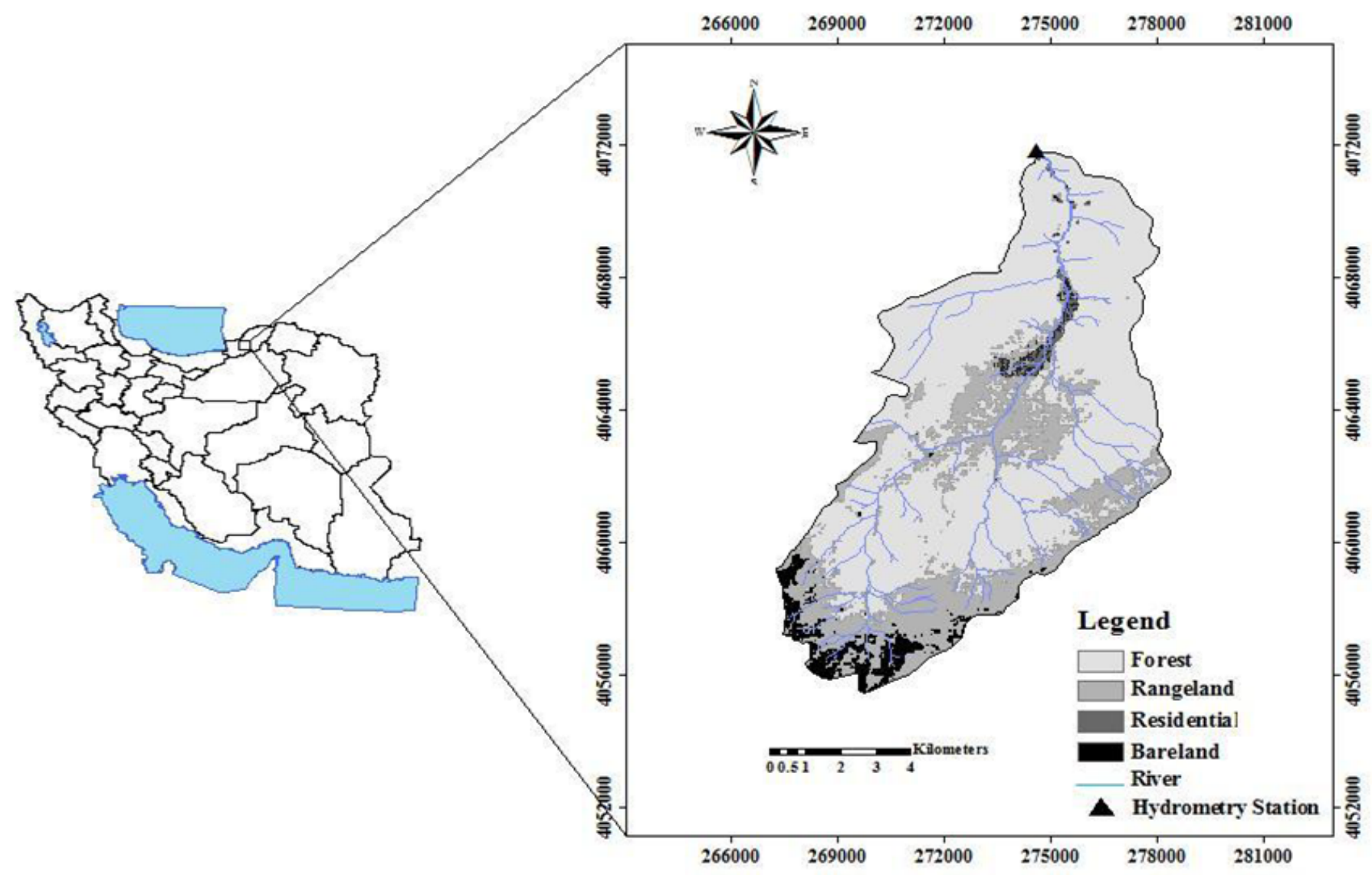

Figure 1: Location of the Ziarat catchment. 


\begin{tabular}{|l|c|c|}
\hline Landsat Number & Sensor & Acquisition Date \\
\hline Landsat 5 & TM & September 5, 1988 \\
\hline Landsat 5 & TM & June 23, 1992 \\
\hline Landsat 7 & ETM+ & July 7, 2002 \\
\hline Landsat 5 & TM & June 23, 2012 \\
\hline
\end{tabular}

Table 1: Landsat Data used over the study period.

expected to affect the value of $\mathrm{Y}, \mathrm{S}_{\mathrm{t}}$ is the seasonal component at time $t, T_{t}$ is the trend in $Y$, and $\alpha_{t}$ is the noise component at time $t$. In trend analysis one wishes to appropriately account for $\mathrm{X}_{t}$, St and $\alpha_{t}$ so that $\mathrm{T}_{t}$ can be detected and accurately quantified [23]. In this study, long term changes of water quality data were investigated using the trend analysis methodology proposed by Helsel and Hirsch [22]. General characteristics of the time series of water quality data (normality of the distribution, presence of seasonality and dependency upon stream flow) were first determined through graphical studies, such as normal Quantile-Quantile plots, box and whisker plots, scatter plots, and statistical hypothesis tests. When necessary, log transformation was applied in attempt to correct anomalies and reduce the number of outlier values. For normally distributed variables, parametric methods (linear regression and analysis of covariance: ANCOVA), and for non-normal variables, nonparametric methods (Mann-Kendall and Seasonal Kendall tests) were applied to detect long term trends [24]. For those variables which were dependent upon flow, the effects of discharge were eliminated (flow adjustment) using ANCOVA and the LOESS method accordingly [25-28]. Seasonal variability was also considered in the analysis using the Seasonal Kendall and ANCOVA for non-normal and normal variables, respectively.

\section{Long-term land use change}

To investigate the likely impact of land use changes on water quality trends, land use changes during the study period were examined [29]. Remote sensing data were used to determine the land use change between the years of 1967, 1988, 1992, 2002, and 2012. The aerial photographs of 1967 were scanned, geo-referenced and visually interpreted to create land use map for the year 1967. Landsat images of 1988, 1992, 2002, and 2012 imported to Clark lab's GIS software IDRISI 14.01 geo-registered, and projected into the Universal Transverse Mercator (UTM) coordinating system. All non-thermal bands of the images were used to create spectral signatures for classification. Five land use classes, including forest, cropland-rangeland, residential areas, roads, and bare lands were considered, based on field surveys and the land use data generated by other studies. The images were classified using the supervised maximum likelihood classification method [30]. The accuracy of the classification was verified by randomly generated reference points using a stratified random algorithm [30]. Field surveys, the historical LULC data, and 1:25,000 topographic maps were used to provide reference information for both the classification and the accuracy assessment. Finally the land use maps for different dates were super-imposed to detect changes in land use over a period of time.

\section{Results}

Normality analysis of the water quality data series by Q-Q plots and Shapiro-Wilk test revealed that $\mathrm{Mg}^{2+}, \mathrm{Ca}^{2+}, \mathrm{HCO}^{3-}$, hardness, and $\mathrm{pH}$ are normally distributed and $\mathrm{Cl}^{-}, \mathrm{TDS}, \mathrm{K}^{+}, \mathrm{Na}^{+}, \mathrm{SAR}$, and $\mathrm{EC}$ have nonnormal distribution. After log-transformation, $\mathrm{Cl}^{-}$and TDS conformed to normal distribution but other variables remained non-normal. To determine whether or not a given water quality variable is dependent upon flow; the scatter plot of the variable against discharge was plotted. Figure 2 displays scatter plots for some of the water quality variables.
Box and whisker plots, showing seasonal trends of selected water quality variables are given in Figure 3. Trend analysis results of the water quality variables using parametric and non-parametric methods are presented in Tables 2 and 3, respectively. The results showed that, of the 12 water quality variables, 10 variables demonstrated statistically significant increasing trend, one variable showed no significant trend,
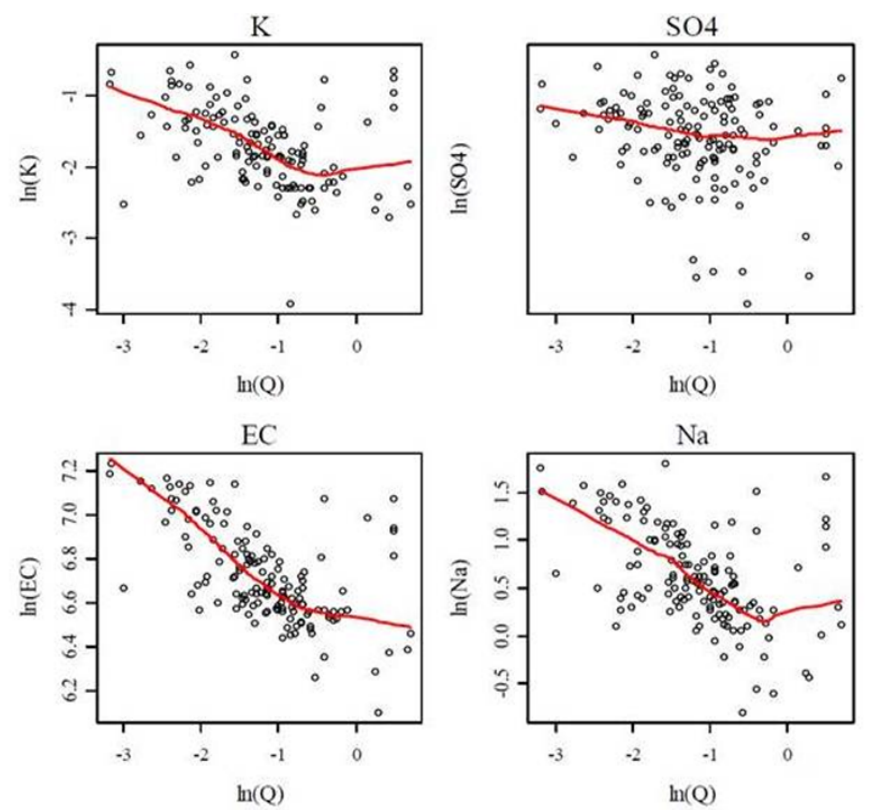

Figure 2: Scatter plots of Ln-transformed water quality variables against Lntransformed flows for the Ziarat River.
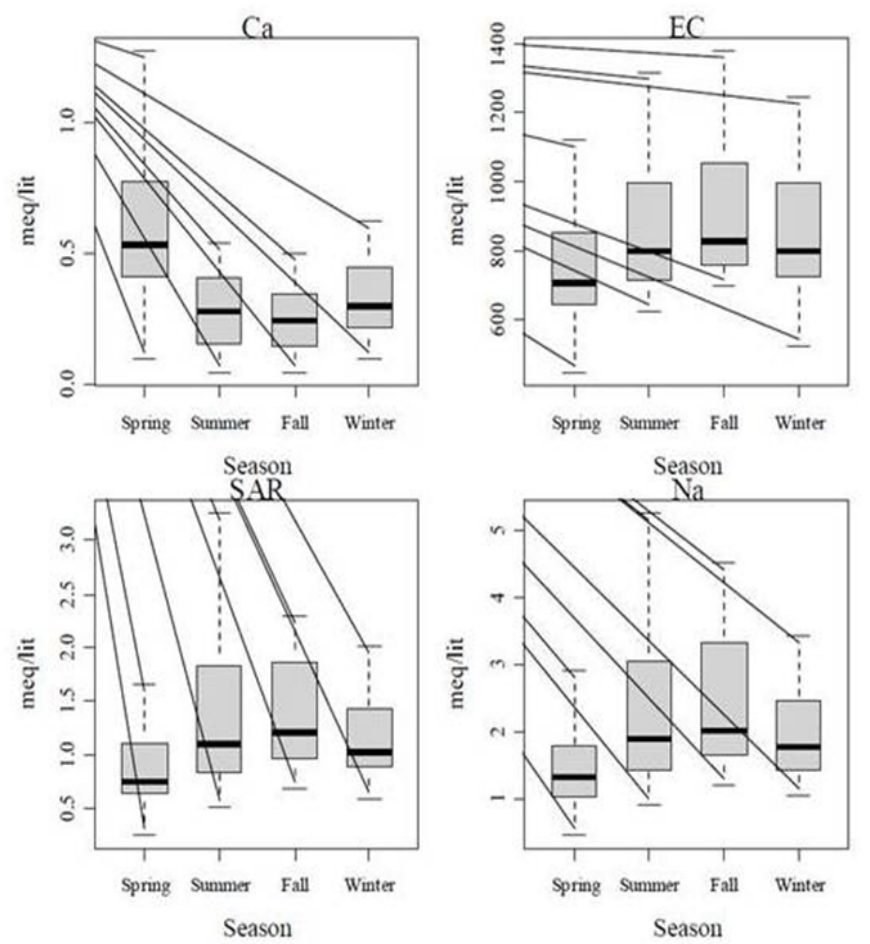

Figure 3: Box plots of water quality variables of Ziarat River in different seasons. 
and only one variable exhibited a decreasing trend. The results of our study on the land use changes in the Ziarat catchment during the period of 1967-2012, are represented in Table 4. The results demonstrate that, during the 45 year period, the area of forests decreased by 981.7 hectares, while the area of cropland rangelands increased by 657.18 hectares, as well as the area of residential areas which increased by 84.28 hectares. The agreement between increasing trends of developed areas (cropland-rangeland, residential, roads), and increasing trends of most of the water quality variables reveals that land use change has been one of the most important factors influencing the river water quality.

\section{Discussion}

The analysis of water quality data reveals the importance of anthropogenic activities in combination with rock-soil-water interaction in the chemistry of the Ziarat River. Based on field observations and measurements, increasing trends of most of the variables can be most likely attributed to factors such as land use change, soil erosion happened particularly on croplands, road construction without technical considerations, high erosion potential for some geologic formation, extensive occurrence of landslides particularly along the drainage network, wastewater generated from domestic activities, and effluents of organic wastes of animal origin into the river. The catchment of the Ziarat River supply water for the catchment inhabitants and also meets about $20-30 \%$ of water demands of Gorgan (the city in downstream of the catchment with a population of about 500000 persons). Therefore, there is growing concern about the potential effects of extensive land use change and resultant changes in the hydrological regime and quality of the water resources of the catchment. Despite its significance, our understanding of water quality attributes and its temporal/spatial variations for the Ziarat River is limited. Although the chemical fertilizers and pesticides effects have not been dealt with in this study, plowing the steep slopes for dry farming throughout the catchment and application of chemical fertilizers and pesticides on these farms, and also construction of access roads can cause non-point source pollution and flushing of soil salts during rainy seasons, when the soil surface is rarely covered with vegetation or plant residues. In the middle parts of the catchment, the existence of shale and marl layers has increased the potential risk of debris flows and landslides occurrence [31]. Fast increasing trend of buildings and roads construction on hill slopes and also replacement of deep-rooted trees with short-rooted crops has a negative impact on the above mentioned hazards that, in turn, leads to water quality changes in the Ziarat River.

Variation of $\mathrm{TH}$ and $\mathrm{HCO}^{3-}$ is possibly due to dissolution of minerals such as calcite through $\mathrm{HCO}^{3-}$ weathering process. In contrast, $\mathrm{EC}, \mathrm{Cl}^{-}$parameters are reactive components that are partially of anthropogenic origin [32]. EC qualitatively reflects the status of inorganic contamination and is a measure of TDS in waters [33]. In the Ziarat River, EC values follow an inverse pattern with the river discharge, which shows the dilution effect. High EC values are observed as a direct result of decreased rainfall/discharge and increased agricultural land use and built-up intensity in the river catchment.

\section{Conclusions}

The results of this study show that, in-stream water quality trends of the Ziarat catchment has been likely related to land use change. Although the study does not provide direct quantification of causality between discovered land use change and water quality trends in the study area, but extensive land use changes and the increasing trends of most of water quality variables supports to some extent the above hypothesis. There are a number of other natural and human-induced driving factors involved that adds to the complexity of the river system and its attributes. The uncertainty in this context needs to be addressed through further investigations. To avoid a serious threat to the health of stream ecosystem and local communities in the Ziarat catchment, pollutants particularly agricultural runoff and human wastes should

\begin{tabular}{|l|c|c|c|}
\hline Water quality variable & Type of test & Coefficient & Trend \\
\hline $\mathrm{Mg}^{2+}$ & ANCOVA & 4.45 & 0.00 \\
\hline $\mathrm{HCO}^{2-}$ & ANCOVA & 18.29 & 0.00 \\
\hline $\mathrm{pH}$ & linear regression & 1.85 & 0.07 \\
\hline $\mathrm{Ca}^{2+}$ & linear regression & 14.30 & Increasing \\
\hline $\mathrm{Cl}^{-}$ & ANCOVA & 11.64 & 0.00 \\
\hline TDS & ANCOVA & 2.19 & 0.00 \\
\hline Hardness & ANCOVA & 8.68 & 0.03 \\
\hline
\end{tabular}

Table 2: Results of trend analysis using parametric methods.

\begin{tabular}{|l|c|c|c|}
\hline Water quality variable & Type of test & Coefficient & Trend \\
\hline $\mathrm{Na}+$ & Mann-Kendall & 0.09 & 0.00 \\
\hline $\mathrm{K}+$ & Seasonal Kendall & 0.18 & 0.00 \\
\hline SO42- & Mann-Kendall & -0.05 & 0.17 \\
\hline EC & Seasonal Kendall & 0.19 & 0.00 \\
\hline SAR & Mann-Kendall & 0.08 & Decreasing \\
\hline
\end{tabular}

Table 3: Results of trend analysis using non-parametric methods.

\begin{tabular}{|c|c|c|c|c|c|c|c|c|c|c|}
\hline \multirow[b]{2}{*}{ land use classes } & \multicolumn{2}{|c|}{1967} & \multicolumn{2}{|c|}{1988} & \multicolumn{2}{|c|}{1992} & \multicolumn{2}{|c|}{2002} & \multicolumn{2}{|c|}{2012} \\
\hline & Area (ha) & Area $(\%)$ & Area (ha) & Percent (\%) & Area (ha) & Percent (\%) & Area (ha) & Area (\%) & Area (ha) & Area (\%) \\
\hline Forest & 7750.3 & 79.9 & 7303.6 & 75.3 & 7291.0 & 75.2 & 6890.7 & 71.1 & 6768.6 & 69.8 \\
\hline Cropland-Rangeland & 1743.5 & 18.0 & 2159.9 & 22.3 & 2075.0 & 21.4 & 2424.3 & 25 & 2400.7 & 24.8 \\
\hline Residential & 13.2 & 0.14 & 44.2 & 0.4 & 46.9 & 0.48 & 68.3 & 0.7 & 97.4 & 1 \\
\hline Barren & 170.7 & 1.8 & 146.7 & 1.5 & 231.5 & 2.4 & 221.7 & 2.3 & 297.7 & 3.1 \\
\hline Road & 20.5 & 0.21 & 43.8 & 0.45 & 53.6 & 0.55 & 92.7 & 0.96 & 133.7 & 1.4 \\
\hline
\end{tabular}

Table 4: Areas of land use classes in different years for the Ziarat catchment. 
Citation: Zamani M, Sadoddin A, Garizi AZ (2013) Assessing Land Cover/ Land Use Change and its Impacts on Surface Water Quality in the Ziarat Catchment, Golestan Province-Iran. Hydrol Current Res 4: 159. doi:10.4172/2157-7587.1000159

Page 5 of 5

be controlled effectively through implementing proper management policies and actions. It seems appropriate to apply the best management practices over the entire catchment to curb some of the environmental issues raised above. Of the best ways to mitigate the downgrading trend of river water quality, establishment of riparian vegetation as well as onsite remediation is recommended.

\section{References}

1. Vörösmarty CJ, Lévêque C, Revenga C, Bros R, Caudill C, et al. (2005) Fresh Water in Millennium Assessment. 165- 207.

2. Khadam IM, Kaluarachchi JJ (2006) Water quality modeling under hydrologic variability and parameter uncertainty using erosion-scaled export coefficients. Journal of Hydrology 330: 354-367.

3. Behbahaninia A, Mirbagheri SA, Khorasani N, Nouri J, Javid AH (2009) Heavy metal contamination of municipal effluent in soil and plants. Food, Agriculture and Environment 7: 851-856

4. Nouri J, Karbassi AR, Mirkia S (2008) Environmental management of coastal regions in the Caspian Sea. International Journal of Environmental Science and Technology 5: 43-52.

5. Bu H, Tan X, Li S, Zhang Q (2009) Water quality assessment of the Jinshui River (China) using multivariate statistical techniques. Environmental Earth Sciences 60: 1631-1639.

6. Soner Kara S, Onut S (2010) A stochastic optimization approach for paper recycling reverse logistics network design under uncertainty. International Journal of Environmental Science and Technology 7: 717-730.

7. Sarkar SK, Saha M, Takada H, Bhattacharya A, Mishra P, et al. (2007) Water quality management in the lower stretch of the river Ganges, east coast of India: an approach through environmental education. Journal of Cleaner Production 15: 1559-1567.

8. Chin DA (2006) Water quality engineering in natural systems. John Wiley \& Sons.

9. Jarvie HP, Whitton BA, Neal C (1998) Nitrogen and phosphorus in east coast British rivers: Speciation, sources, and biological significance. Science of the Total Environment 210-211: 79-109.

10. Giridharan L, Venugopal T, Jayaprakash M (2009) Assessment of water quality using chemometric tools: A case study of River Cooum, South India. Archives of Environmental Contamination and Toxicology 56: 654-669.

11. Nouri J, Khorasani N, Lorestani B, Karami M, Hassani AH, et al. (2009) Accumulation of heavy metals in soil and uptake by plant species with phytoremediation potential. Environmental Earth Sciences 59: 315-323.

12. Groppo JD, Moraes JMD, Beduschi CE, Genovez AM, Martinelli LA (2008) Trend analysis of water quality in some rivers with different degrees of development within the Saopaulo state, Brazil. River Research and applications 24: 1056-1067.

13. Walling DE, Fang D (2003) Recent trends in the suspended sediment loads of the world's rivers. Global and Planetary Change 39: 111-126.

14. Maasdam R, Claassen THL (1998) Trends in water quality and algal growth in shallow Frisian lakes, The Netherlands. Water Science \& Technology $37:$ $177-184$.
15. Park GS, Park SY (2000) Long-term trends and temporal heterogeneity of water quality in tidally mixed estuarine waters. Marine Pollution Bulletin 40: 1201-1209.

16. Larsen SE, Kronvang B, Windolf J, Svendsen LM (1999) Trends in diffuse nutrient concentrations and loading in Denmark: Statistical trend analysis of stream monitoring data. Water Science \& Technology 39: 197-205.

17. Helsel DR, Hirsch RM (1992) Statistical methods in water resources. Studies in Environmental Science 49 Elsevier.

18. Paul MB, Linfield CB (1997) Statistics for Environmental Engineers. Lewis publishers.

19. Potts JM, Hirst D, Miller JD, Edwards AC, Elston DA (2003) Comparison of trends in stream water quality. Hydrological Processes. 17: 2449-2462.

20. Zare Garizi A, Sheikh V, Sadoddin A (2011) Assessment of seasonal variations of chemical characteristics in surface water using multivariate statistical methods. International Journal of Environmental Science and Technology 8: 581-592.

21. Esterby SR (1996) Review of methods for the detection and estimation of trends with emphasis on water quality applications. Hydrological Processes 10: 127- 149.

22. Helsel DR, Hirsch RM (2002) Statistical Methods in Water Resources Techniques of Water-Resources Investigations of the United State Geological Survey. Hydrologic analysis and interpretation.

23. McLeod Al, Hipel KW, Bodo BA (1991) Trend analysis methodology for water quality time series. Environmetrics 2: 169-200.

24. Hirsch RM, Slack JR, Smith RA (1982) Techniques of trend analysis for monthly water quality data. Water Resources Research 18: 107-121.

25. Cleveland WS, Devlin SJ (1988) Locally weighted regression: an app roach to regression analysis by local fitting. Journal of the American Statistical Association 83: 596-610.

26. Lettenmaier DP, Hooper ER, Wagoner C, Faris KB (1991) Trends in stream quality the Continental United States 1978 -1987. Water Resource Research 27: $327-340$.

27. Walker WW (1991) Water quality trends at inflows to Everglades National Park. Journal of the American Water Resource Association 27: 59 -72.

28. Chang $\mathrm{H}$ (2008) Spatial analysis of water quality trends in the Han River basin South Korea. Water Research 42: 3285-3304

29. Worrall F, Burt TP (1999) The impact of land-use change on water quality at the catchment scale: the use of export coefficient and structural models. Hydrology 221: $75-90$.

30. Jensen JR (1996) Introductory Digital Image Processing: A Remote Sensing Perspective. Prentice Hall, p. 526.

31. Mousavi SM (2012) Application of Rosgen classification for the Ziara watershed, Gorgan. American Science 8: 184-189.

32. Khazheeva ZI, Tulokhonov AK, Dashibalova LT (2007) Seasonal and spatial dynamics of TDS and major ions in the Selenga River. Water Research 34 444-449.

33. McCutcheon SC, Martin J, Barnwel TO (1993) Water quality. In D Maidment (Eds.), Handbook of Hydrology, New York, NY: McGraw-Hill, USA. 